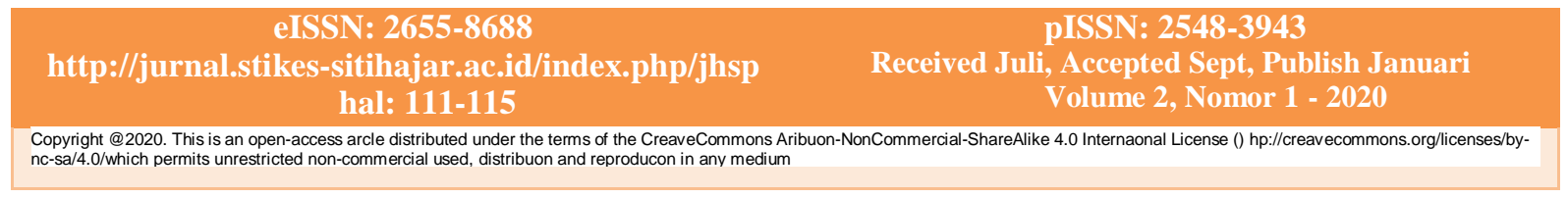

\title{
Penggunaan Madu dan Mangga (Mangifera indica) pada Penyembuhan Luka
}

\author{
Alinta Ayuningtyas ${ }^{*}$ \\ ${ }^{1}$ Fakultas Kedokteran, Universitas \\ Lampung \\ J1. Prof. Dr. Ir. Sumantri Brojonegoro No. 1, Bandar Lampung, Lampung, Indonesia \\ Email: alintaayuningtyas27@ gmail.com
}

\begin{abstract}
ABSTRAK
Penggunaan obat-obatan tradisional seperti tanaman sudah dilakukan secara turun temurun untuk menyembuhkan berbagai penyakit. Salah satunya adalah penggunaan mangga (Mangifera indica) dan madu sebagai obat untuk menyembuhkan luka. Madu dengan komponen antimicrobial dan antioksidan yang mampu menyembuhkan luka. Madu juga dapat memberikan efek lapisan protektif dan menjaga kelembaban sehingga bakteri tidak dapat berkembang. Mangga mengandung mangiferin yang merupakan komponen yang dapat menyembuhkan luka dengan adanya vitamin A dan vitamin $\mathrm{C}$ yang penting dalam proses pembentukan kolagen dan jaringan ikat sehingga terjadi penyembuhan luka. Penggunaan campuran madu dan mangga diketahui dapat mempercepat proses penyembuhan luka dibandingkan jika digunakan secara terpisah.
\end{abstract}

Kata kunci: penyembuhan luka, madu, dan mangga (Mangifera indica)

\section{ABSTRAK}

The use of traditional medicines such as plants has been done for generations to cure various diseases. One is the use of mango (Mangifera indica) and honey as a medicine to heal wounds. Honey with antimicrobial components and antioxidants that can heal wounds. Honey can also provide a protective effect and retain moisture so that bacteria cannot develop. Mango contains mangiferin which is a component that can heal wounds in the presence of vitamin $A$ and vitamin $C$ which are important in the process of formation of collagen and connective tissue resulting in wound healing. The use of a mixture of honey and mango is known to accelerate the wound healing process compared to when used separately.

Keyword: wound healing, honey, and mango (Mangifera indica) 


\section{Pendahuluan}

Penggunaan tanaman sebagai obat untuk menyembuhkan berbagai penyakit telah dilakukan secara turun temurun dan menjadi sebuah kebiasaan pada masyarakat di Indonesia, seperti penggunaan jahe dan kunyit atau yang sering disebut sebagai jamu (Sari, Yuniar, Siahaan, Riswati, \& Syaripuddin, 2015). Penggunaan tanaman sebagai obat tidak hanya menyembuhakan keluhan seperti batuk, namun juga pada penyembuhan luka. Secara umum pelayanan kesehatan masyarakat merupakan sub sistem pelayanan kesehatan yang tujuan utamanya adalah pelayanan preventif (pencegahan) dan promotif (peningkatan kesehatan) dengan sasaran masyarakat (Sulaiman \& Anggriani, 2019). Tanaman mangga merupakan salah satu tanaman yang berpotensi menjadi tanaman obat. Mangga (Mangifera indica) adalah salah satu tanaman yang berpotensi sebagai obat herbal karena mengandung senyawa metabolit sekunder. Berbagai bagian dari mangga dapat digunakan sebagai obat, seperti daun mangga yang dapat digunakan untuk mengobati batuk, rasa terbakar, dan menyembuhkan luka. Selain itu buah mangga yang sudah matang dapat membantu melancarkan pencernaan (Masud Parvez \& Masud Parvez, 2016). Pada masyarakat di India, daun mangga (Mangifera indica) digunakan sebagai salah satu obat untuk menyembuhkan luka bakar (Bailung \& Puzari, 2016). Mangga memiliki senyawa seperti saponin, tannin, dan flavonoid yang dapat menyembuhkan luka (Risa, Pantiwati, Mahmudati, Husamah, \& Miharja, 2018).

Selain penggunaan tanaman, madu juga sering digunakan sebagai obat untuk menyembuhkan berbagai penyakit, seperti luka bakar dan luka kronis (Majtan, 2014; Oryan, Alemzadeh, \& s Moshiri, 2016). Madu memiliki sifat antimikrobial spectrum luas dan senyawa yang dapat menyebabkan percepatan penyembuhan luka (Majtan, 2014). Menurut penelitian Sushanth, Lakshmi, \& Reddy (2016), penggunaan campuran madu dan mangga dapat mempercepat penyembuhan luka dibandingkan penggunaan madu saja atau mangga saja atau campuran madu dengan tanaman lainnya. 
Kulit terdiri dari 5 lapisan yaitu stratum basalis, stratum spinosum, stratum granulosum, stratum lusidum, dan stratum korneum. Lapisan-lapisan ini termasuk dalam bagian dari dermis. Dermis merupakan jaringan ikat padat yang berasal dari mesoderm dan merupakan lapisan kulit utama selain epidermis. Proses penyembuhan luka terdiri dari 4 fase yaitu inflamasi, debridemen, proliferasi, dan maturasi.

(1) Fase inflamasi terjadi akibat respon seluler dan vascular akibat rusaknya suatu jaringan, fase ini bertujuan untuk menghentikan perdarahan.

(2) Fase debridement terjadi pada hari ketiga hingga hari keenam setelah cedera dan melibatkan neutrophil untuk membersihkan organisme-organisme yang dapat mengontaminasi.

(3) Pada fase proliferasi, fibroblast jaringan sekitar luka akan bergerak kedalam luka kemudian akan berkembang dan menyekresikan substansi seperti elastin, kolagen, asam hialuronat, fibronectin, dan proteoglikan yang berperan penting dalam membuat jaringan baru,

(4) Fase maturasi dimana pada fase ini terjadi penyempurnaan jaringan yang terbentuk sehingga menjadi jaringan yang kuat (Bamidele et al., 2017; Ramadhian \& Widiastini, 2018).

Madu terdiri atas air sukrosa, glukosa, fruktosa, asam amino, lilin, serbuk sari, pigmen, dan berbagai enzim serta mineral. Enzim-enzim yang ada seperti glukosa oksidase mengoksidasi glukosa menjadi asam glukonik sehingga membuat $\mathrm{pH}$ madu antara 3,2 sampai dengan 5,5 yang membuat madu menjadi asam sehingga membuat mikroba tidak dapat berkembang. Dengan $\mathrm{pH}$ yang rendah ini juga menginhibisi aktivitas protease, sehingga memengaruhi factor pertumbuhan dan serat-serat protein yang penting untuk proses penyembuhan luka. Radikal bebas dari inflamasi yang berkepanjangan dapat menyebabkan rusaknya jaringan dan mencegah penyembuhan. Pada sel-sel yang terpapar madu, menunjukan secara histologis memiliki level antioksidan lebih tinggi dan penurunan jumlah sel inflamasi. Madu juga memberikan efek lapisan protektif dan menjaga kelembaban sehingga bakteri tidak dapat berkembang (Stewart, McGrane, \& Wedmore, 2014).

Pada buah manga terdapat mangiferin yang merupakan antioksidan polifenolik dan glucosylxanthone, dan memiliki antioksidan yang kuat, hipotensif, kemampuan untuk penyembuhan luka, dan imunomodulasi (Sushanth et al., 2016). Selain itu, buah mangga juga memiliki serat pre-biotik, berbagai vitamin dan mineral, serta komponen poly-phenolic flavonoid. Mangga merupakan sumber vitamin A yang baik, dimana vitamin A dibutuhkan untuk menjaga kesehatan membran mucus dankulit. Selain itu, mangga juga memiliki vitamin B6, vitamin C, dan vitamin E. Mengonsumsi makanan yang kaya akan vitamin C membantu tubuh untuk resisten terhadap agen-agen infeksius dan radikal bebas yang berbahaya (Kalita, 2014). Beberapa penelitian menunjukan bahwa mangga memiliki sifat antimicrobial, antifugal, astringenic, danhemostatik. Komponen natural inilah yang memicu terjadinya penyembuhan dan regenerasi dari jaringan (Bamidele et al., 2017). Mangiferin pada buah mangga menunjukan aktivitas penyembuhan luka dengan adanya vitamin A dan Vitamin $\mathrm{C}$. Vitamin A membantu pada pembentukan epitel dan tulang, serta meningkatkan fungsi system imun dan diferensiasi sel. Sedangkan vitamin C dibutuhkan pada pembentukan kolagen, peningkatan imunitas, proteoglikan, dan komponen organic lainnya pada matriks intraselular pada jaringan seperti tulang, kulit, dinding kapiler, dan jaringan ikat lainnya (Sushanth et al., 2016).

Pada penelitian Sushanth et al.(2016), mencampurkan bubuk mangga kering dengan madu untuk melihat penyembuhan luka pada tikus putih. Didapatkan hasil bahwa pada 
kelompok dengan penggunaan campuran madu dan bubuk daun mangga kering 500 $\mathrm{mg} / \mathrm{KgBB}$ menunjukan terjadi penyembuhan luka yang cepat dibandingkan dengan penggunaan vitamin E $200 \mathrm{mg} / \mathrm{KgBB}$. Pada kelompok yang diberikan obat campuran, didapatkan hasil bahwa terjadi proses penyembuhan luka pada hari kedua sedangkan pada kelompok dengan pengobatan standard penyembuhan luka baru terjadi pada hari keempat. Pada kelompok obat campuran $500 \mathrm{mg} / \mathrm{KgBB}$, luka seluruhnya sembuh pada hari ke-10 sedangkan pada kelompok lain luka baru seluruhnya sembuh pada hari ke-12. Pada penelitian Sushanth et al. Menyatakan bahwa penggunaan campuran madu dan bubuk mangga kering secara bersamaan dapat menyembuhkan luka lebih cepat dibandingkan pemakaian madu dan bubuk daun mangga kering secara terpisah.

\section{Ringkasan}

Penggunaan obat tradisional seperti madu dan mangga sebagai obat untuk penyembuhan luka sudah dilakukan secara turun temurun. Madu dengan komponen antibakterial, antioksidan, dan dapat melembabkan dapat membantu penyembuhan luka. Mangga memiliki mangiferin yang merupakan komponen yang dapat membantu penyembuhan luka karena memiliki vitamin $\mathrm{A}$ dan vitamin $\mathrm{C}$ yang penting dalam proses pembentukan kolagen dan penyembuhan luka. Penggunaan madu dan bubuk mangga kering dapat memepercepat proses penyembuhan luka.

\section{Kesimpulan}

Berdasarkan tinjauan pustaka diatas didapatkan bahwa penggunaan madu dan mangga secara bersamaan dapat mempercepat penyembuhan luka dibandingkan dengan penggunaan secara terpisah.

\section{Referensi}

Bailung, B., \& Puzari, M. (2016). Traditional use of plants by the Ahoms in human health management in upper Assam, India. Journal of Medicinal Plants Studies, 4(2), 48-51.

Bamidele, O., Kolawole, J., Ayoka, A., Babatunde, L., Onaseso, O., \& Adedeji, G. (2017). Wound Healing Potentials of Aqueous Leaf Extract of Mangifera indica L. in Wistar Rats. Journal of Complementary and Alternative Medical Research, 2(4), 1-11. https://doi.org/10.9734/jocamr/2017/32409

Kalita, P. (2014). An overview on Mangifera indica: Importance and its various pharmacological action. PharmaTutor, 2(12), 72-76.

Majtan, J. (2014). Honey: An immunomodulator in wound healing. Wound Repair and Regeneration, 22(2), 187-192. https://doi.org/10.1111/wrr.12117

Masud Parvez, G., \& Masud Parvez, C. G. (2016). Pharmacological Activities of Mango (Mangifera Indica): A Review. Journal of Pharmacognosy and Phytochemistry JPP, 1(53), $1-7$.

Oryan, A., Alemzadeh, E., \& Moshiri, A. (2016). Biological properties and therapeutic activities of honey in wound healing: A narrative review and meta-analysis. Journal of Tissue Viability, 25(2), 98-118. https://doi.org/10.1016/j.jtv.2015.12.002

Ramadhian, M. R., \& Widiastini, A. A. (2018). Kegunaan Ekstrak Daun Pepaya (Carica papaya) Pada Luka. J Agromedicine, 5(1), 513-517.

Risa, A. M., Pantiwati, Y., Mahmudati, N., Husamah, H., \& Miharja, F. J. (2018). Daun Mangga (Mangifera indica L): Potensi Baru Penyembuh Luka Sayat. Biota, 11(2), 96-106. https://doi.org/10.20414/jb.v11i2.128

Sari, I. D., Yuniar, Y., Siahaan, S., Riswati, R., \& Syaripuddin, M. (2015). Tradisi Masyarakat dalam Penanaman dan Pemanfaatan Tumbuhan Obat Lekat di Pekarangan. Jurnal Kefarmasian Indonesia, 5(2), 123-132. https://doi.org/10.22435/jki.v5i2.4407.123-132 
Stewart, J. A., McGrane, O. L., \& Wedmore, I. S. (2014). Wound care in the wilderness: Is there evidence for honey? Wilderness and Environmental Medicine, 25(1), 103-110. https://doi.org/10.1016/j.wem.2013.08.006

Sulaiman, \& Anggriani. 2019. Hubungan Mutu Pelayanan Terhadap Kepuasan Pasien di Poli Fisioterapi RSU Siti Hajar. Jurnal Endurance: Kajian Ilmiah Problema Kesehatan, 4(2), 252-261.

Sushanth, K. A., Lakshmi, K. C., \& Reddy, D. S. (2016). Evaluation of wound healing activity with a new formulation of dry Mangifera indica and honey using swiss albino mice. Asian Journal of Pharmaceutical and Clinical Research, 9(4), 139-142. 